\title{
The physics of gas chimney and pockmark formation, with implications for assessment of seafloor hazards and gas sequestration
}

\author{
L.M. Cathles ${ }^{\mathrm{a}, *}$, Zheng Su ${ }^{\mathrm{b}}$, Duofu Chen ${ }^{\mathrm{c}}$

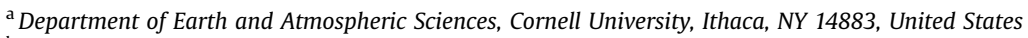 \\ ${ }^{\mathrm{b}}$ CAS Key Laboratory of Renewable Energy and Gas Hydrate, Guangzhou Institute of Energy Conversion, Chinese Academy of Sciences, Wushan, Guangzhou 510640, China \\ ${ }^{c}$ CAS Key Laboratory of Marginal Sea Geology, Guangzhou Institute of Geochemistry, Chinese Academy of Sciences, Wushan, Guangzhou 510640, China
}

\section{A R T I C L E I N F O}

\section{Article history:}

Received 26 January 2009

Received in revised form

24 August 2009

Accepted 24 September 2009

Available online 30 September 2009

\section{Keywords:}

Hydrate seal

Capillary seal

Quick sediments

Gas seepage

Gas chimneys

Rate of gas chimney formation

Pockmarks

Seafloor hazards

Risk

$\mathrm{CO}_{2}$ sequestration

\begin{abstract}
A B S T R A C T
Pockmarks form where fluids discharge through seafloor sediments rapidly enough to make them quick, and are common where gas is present in near-seafloor sediments. This paper investigates how gas might lead to pockmark formation. The process is envisioned as follows: a capillary seal traps gas beneath a fine-grained sediment layer or layers, perhaps layers whose pores have been reduced in size by hydrate crystallization. Gas accumulates until its pressure is sufficient for gas to invade the seal. The seal then fails completely (a unique aspect of capillary seals), releasing a large fraction of the accumulated gas into an upward-propagating gas chimney, which displaces water like a piston as it rises. Near the seafloor the water flow causes the sediments to become "quick" (i.e., liquefied) in the sense that grain-to-grain contact is lost and the grains are suspended dynamically by the upward flow. The quickened sediment is removed by ocean-bottom currents, and a pockmark is formed. Equations that approximately describe this gas-piston-water-drive show that deformation of the sediments above the chimney and water flow fast enough to quicken the sediments begins when the gas chimney reaches half way from the base of its source gas pocket to the seafloor. For uniform near-surface sediment permeability, this is a buoyancy control, not a permeability control. The rate the gas chimney grows depends on sediment permeability and the ratio of the depth below seafloor of the top of the gas pocket to the thickness of the gas pocket at the time of seal failure. Plausible estimates of these parameters suggest gas chimneys at Blake Ridge could reach the seafloor in less than a decade or more than a century, depending mainly on the permeability of the deforming near-surface sediments. Since these become quick before gas is expelled, gas venting will not provide a useful warning of the seafloor instabilities that are related to pockmark formation. However, detecting gas chimney growth might be a useful risk predictor. Any area underlain by a gas chimney that extends half way or more to the surface should be avoided.
\end{abstract}

(c) 2009 Elsevier Ltd. All rights reserved.

\section{Introduction}

Pockmarks (Fig. 1) are nearly circular depressions that form where fluids escape upward through fine-grained seafloor sediments. They were first described by King and MacLean (1970) on the Scotian Shelf. More than 30 years of subsequent research has shown that they are typically concentrated in fields a few square kilometers in area within which there are hundreds to thousands of pockmarks per square kilometer. Their length-to-breadth ratio generally varies from 1 (circular) to $\sim 1.25$. Their depths range from 1 to $80 \mathrm{~m}$ but are usually $<10 \mathrm{~m}$. Their diameters range from a few to $>300 \mathrm{~m}$, but larger pockmarks can be often seen to be agglomerations of "unit

\footnotetext{
* Corresponding author.

E-mail address: Imc19@cornell.edu (L.M. Cathles).
}

pockmarks" that have diameters of $<5 \mathrm{~m}$ and depths of a few meters (Hovland and Judd, 1988).

Pockmarks are commonly located in areas where gas is present in near-surface sediments, as indicated by acoustic turbidity. Often pockmarks are located where acoustically transparent gas chimneys breach the seafloor (Fig. 2). In this case the pockmark usually has the same diameter as the chimney. Gas chimneys can often be seen to originate at the top of shallow gas pockets. At water depths greater than $\sim 500 \mathrm{~m}$, gas pockets are commonly trapped at the base of the hydrate stability zone. Persistent gas leakage through pockmarks is common. This supports vent communities and causes carbonate cementation which produces hardgrounds that can be detected and mapped by sonar. (Hovland and Judd, 1988; Judd and Hovland, 2007; Hovland et al., 2002, 2005; Hovland, 2005; Hovland and Svensen, 2006; Gay et al., 2006a,b, 2007; Paull et al., 1995, 2008). 


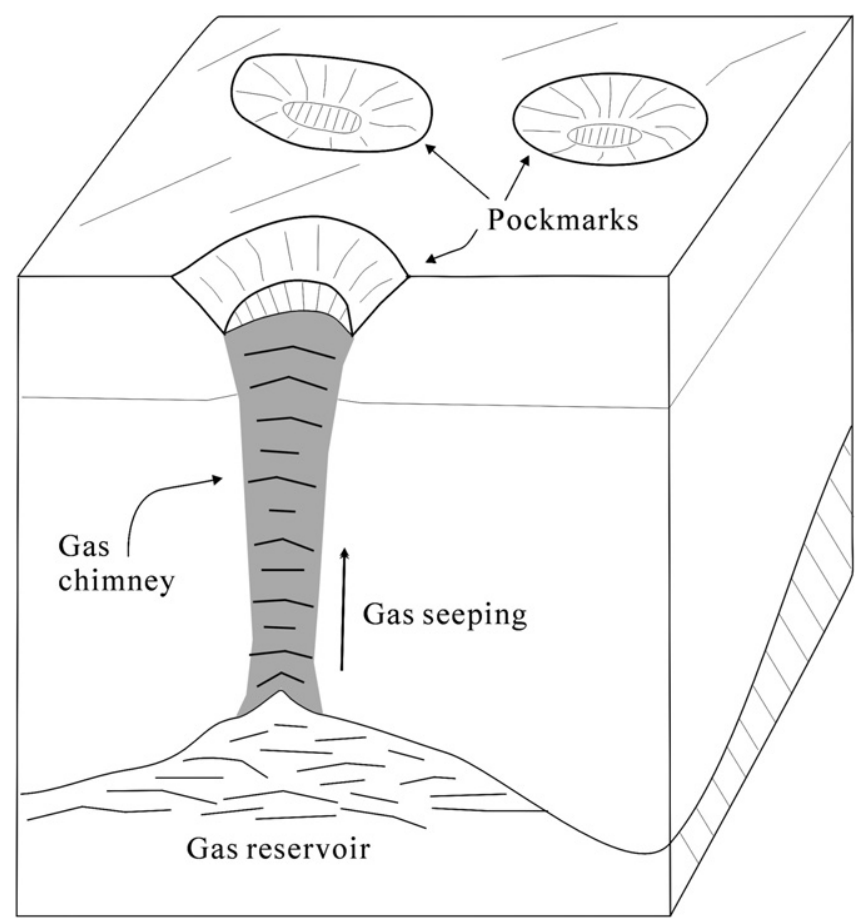

Fig. 1. Pockmarks are frequently located atop gas chimneys. Slow, continued gas leakage through the chimneys sustains vent communities which produce carbonate mounds in the pockmarks. Figure modified from Hovland (1989).

Pockmarks appear to form very rapidly. A pre-construction site survey in the Arabian Gulf showed no pockmarks, whereas a postconstruction survey revealed 7 pockmarks, of which 5 were active seeps (Hovland and Judd, 1988, p. 85). Pockmarks are observed in areas with strong bottom currents where all but the most recently

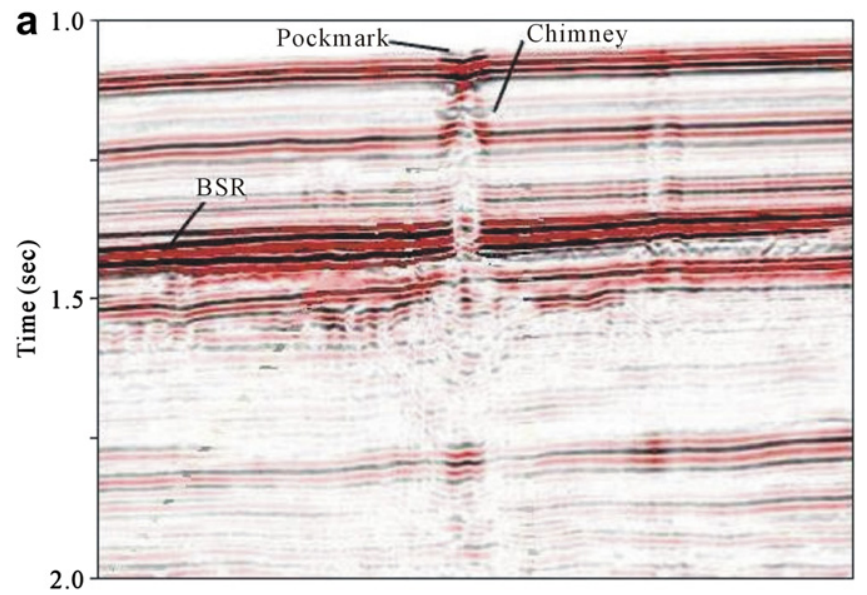

b

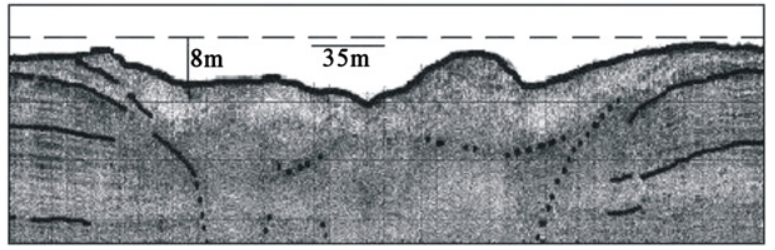

Fig. 2. Seismic profiles of a gas chimney with a pockmark at its top. Taken from the flanks of the Storegga Slide off Norway (Hovland et al., 2005; Paull et al., 2008). The acoustically transparent gas chimney links the pockmark to an underlying bottom simulating reflector (BSR) not shown in the diagram. The pockmark is $\sim 8 \mathrm{~m}$ in depth and $\sim 200$ across. formed would have rapidly filled with sediment (ibid., p. 85, 94). The South Fladen area of the North Sea has high pockmark density and was intensively studied by the British Geological Survey from 1974 to 1978 . Repeat surveys there indicated that pockmarks were growing. During the surveying, massive sediment plumes were observed that probably derived from pockmarks in the process of enlargement. The large dark clouds on the sonar record were clearly suspended solids, not gas, because they dispersed slowly over a few hours by settling to the seabed rather than dispersing rapidly upward, as would be expected for gas (ibid., p. 25).

Pockmark formation has been observed. The jackup rig J Storm II in the Gulf of Mexico tilted, was evacuated, and sank 10 min later. A flat-bottomed crater $500 \mathrm{~m}$ across and $12 \mathrm{~m}$ deep was formed. Gas venting was observed after the rig collapsed, but apparently was not observed as a precursor to the event (ibid., p. 248). In the Tordis field of the North Sea, water injected $\sim 800 \mathrm{~m}$ below the seafloor produced a pockmark $\sim 40 \mathrm{~m}$ in diameter and 7-8 $\mathrm{m}$ deep (published in the Norwegian press; summarized by F. Riis, 2009). At South Pass Block 78 in the Gulf of Mexico, a pockmark $600 \mathrm{~m}$ in diameter and $30 \mathrm{~m}$ deep formed when a gas pocket caused a blowout during drilling (Hovland and Judd, 1988, p. 248).

Pockmarks are of interest for several reasons. They vent methane that is oxidized by bacteria, which in turn provide the base of the food chain for vent communities. They often indicate active petroleum generation, and thus are of interest in oil and gas exploration. As unstable elements on the seafloor they must be factored into any safety assessment of seafloor infrastructures. As points of discharge for greenhouse gases they potentially have climate implications.

One of their most interesting aspects, as emphasized by Hovland and Judd (1988), is that they show that fluids can pass relatively easily through fine-grained surficial sediments, and directly reveal the pattern of near-surface permeability. Initial fluid escape appears to be guided by small cracks. Perhaps the most dramatic evidence of this is the preferential location of pockmarks along iceberg plough furrows (Hovland and Judd, 1988, p. 13). The icebergs are thought to have produced stress cracks that localized fluid escape. The cracks were subsequently enlarged and pockmarks formed. Pockmarks commonly form at the margins of salt domes (Schmuck and Paull, 1993; Taylor et al., 2000), along structures in bedrock (Shaw et al., 1997), and along faults and faulted anticlines (Eichhubl et al., 2000; Dimitrov and Woodside, 2003). Pockmarks form along joints in hardground in the Arabian Gulf (Hovland and Judd, 1988, p. 85). Polygonal faults allow fluids to escape from vertically stacked turbiditic palaeochannels in the Low Congo Basin, resulting in an unusual polygonal pattern of pockmarks (Fig. 3b; Gay et al., 2006a).

The currently accepted conceptual model for pockmark formation is that articulated by Hovland and Judd (1988) for thermogenic gas. Gas generated at depth migrates upward through a series of minor reservoirs. Accumulation in near-seabed sediments produces domes on the seafloor (Judd and Hovland, 2007, p. 12) and small tension fractures on these domes allow gas escape. As gas venting enlarges the small cracks, the venting velocity and erosion increase, culminating in a violent burst of escaping gas which produces a unit pockmark. Unit pockmarks continue to develop, cluster around the former dome, and coalesce to form a "fully-grown" composite pockmark. Once produced, the permeable pathways to the surface allow continued slow gas venting that drains gas from adjacent areas for a year or so, after which the pockmark becomes dormant. The pockmark may be re-activated by a later pulse of gas. Vertical stacks of pockmarks in the subsurface suggest this (Judd and Hovland, 2007, p. 74). In most areas the repeat time of pockmark activity is unknown. The formation of new pockmarks in a pockmarked area is believed to be rare because established vent channels promote the freshening of old pockmarks rather than the formation of new ones. (Hovland and Judd, 1988, pp. 140-142). 

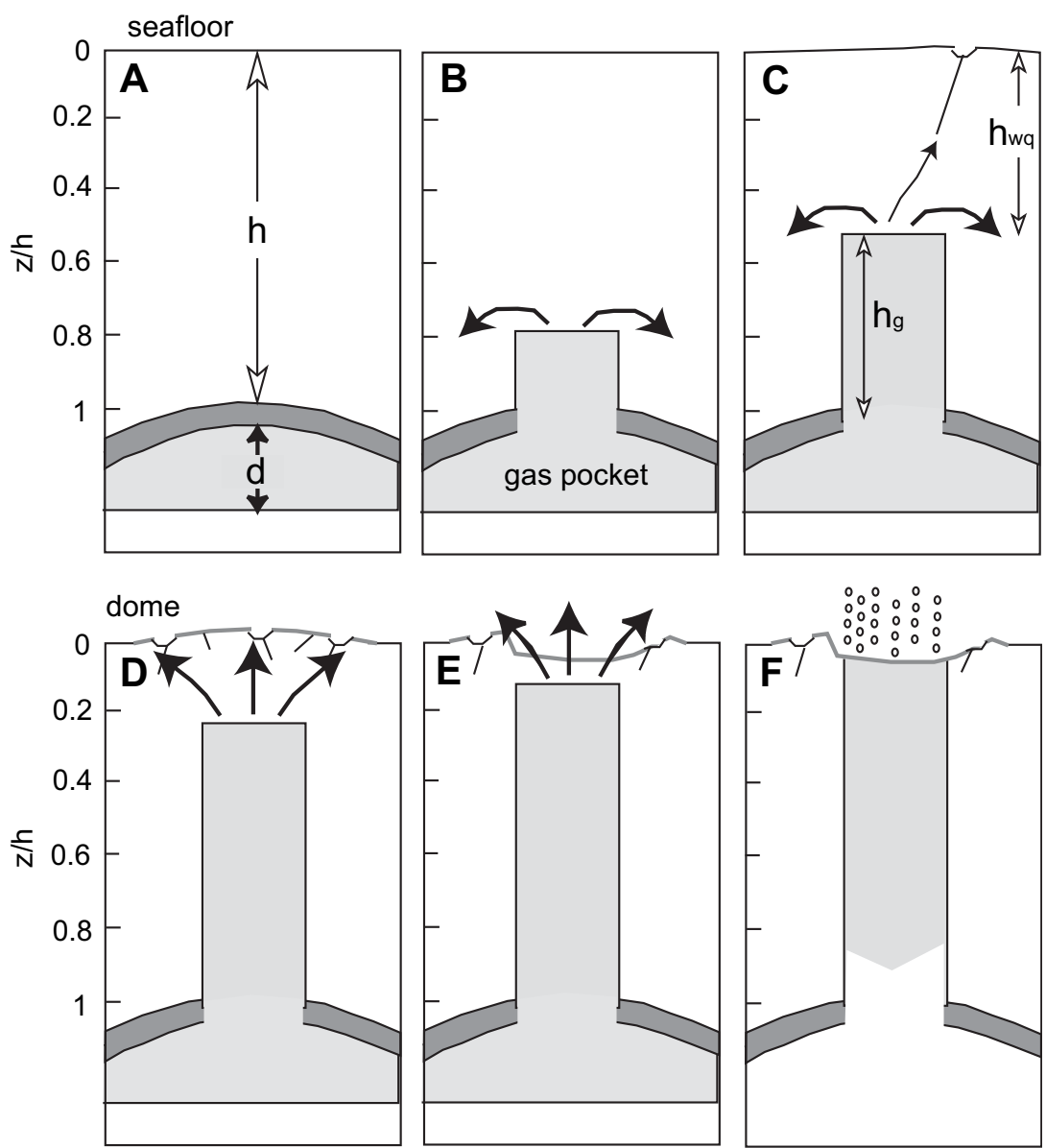

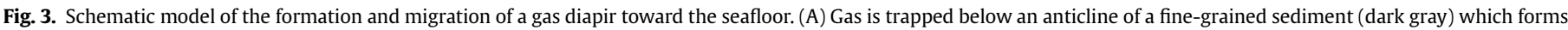

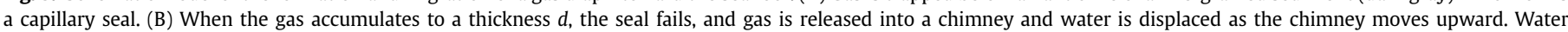

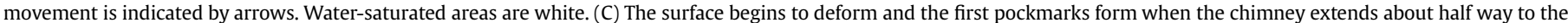

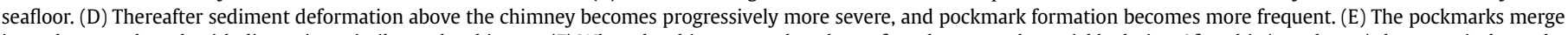

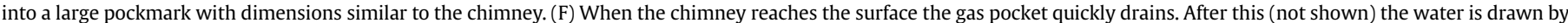

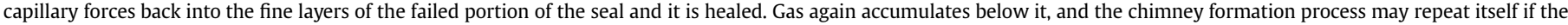
gas again accumulates to a thickness $d$.

There are a number of things that the Hovland and Judd model either does not address or does not fully explain. The first is that the nature of the fluid that forms a pockmark is more uncertain that might be expected. Hovland and Judd (1988, p. 120) state: "The evidence for the formation of pockmarks by fluid escape is now overwhelming; yet the nature of the fluid is varied, and its exact role is not always the same." Specifically, sometimes it appears the pockmark-forming fluid is water and sometimes gas.

A second recognized problem is how gas is introduced into the sediments. It need only be present in very small amounts to be observed seismically. At low saturations gas is not mobile. So how was it introduced and what does the process imply? Pockmarks that sit atop gas chimneys with the same diameter, but what controls the diameter of a gas chimney? Both mud volcanoes and pockmarks form in the same environment; both vent gas, and both form quickly. How are the two related? What controls the periodicity of pockmark formation and how can the periodicity be predicted?

These questions all involve the movement of water and gas and fundamentally ask how the flow of water and gas are related. The purpose of this paper is to show how capillary phenomena can elucidate these issues. This is done first conceptually and then more quantitatively with simplified analytical expressions. The simplifications and implications are discussed in the last section.

\section{Conceptual model}

The presence of gas (or any other non-wetting phases) makes possible highly non-linear flow phenomena, and in particular allows the rapid release of large volumes of gas. This is because gas and water physically interfere with each other's flow. Capillary forces pull the wetting phase (water) into the finer pores, displacing gas to the larger pores. Gas bubbles in the larger pores must deform to enter finer pores, and decreasing their radius requires a force. This means a pressure drop must develop to drive gas into and across each layer of fine-grained sediment. Water is blocked by the gas bubbles that are pressed against the fine pores, so the flow of both phases is blocked. This is a generalization of the single interface capillary sealing that traps petroleum. Description of laboratory experiments that demonstrate and elucidate this generalization is given in Cathles (2001, 2003) and Shosa and Cathles (2001).

The essential requirement for a capillary seal is that two fluids are present. If a single fluid, for example gas, penetrates the seal, the seal completely disappears and offers little resistance to the nearcomplete and rapid release of gas from the pocket (e.g., Cathles, 2007). The process we envision is that gas is trapped below a finegrained layer or set of layers and accumulates. The pressure at the base of the gas pocket is hydrostatic. The pressure at the top of the gas pocket is much greater than hydrostatic because of the low gas 
density. As the thickness of the gas pocket grows, the excess gas pressure at its top increases and eventually becomes sufficient to force the gas through the topographically highest part of the seal. At this point the seal fails and gas in the pocket is discharged into a gas chimney which grows upward toward the seafloor as illustrated in Fig. 3. Capillary barriers will form where water and gas mix at the sides and top of the chimney. Two fluids are present at these locations and the capillary barriers that result will give the chimney a relatively flat top and limit its width. The diameter of the chimney is controlled by the relative frequency of lateral and vertical finecoarse sediment interfaces (e.g., Erendi and Cathles, 2001). Sediments are typically deposited in pancake-shaped units and thus the fine-coarse interfaces will be encountered laterally as well as vertically, albeit at much greater spatial intervals.

The impact of these lateral and vertical capillary barriers can, we think, be seen in the pattern with which $\mathrm{CO}_{2}$ is filling strata in the Sleipner $\mathrm{CO}_{2}$ injection site in the Norwegian sea. From 1996 to 2001 about $4.3 \times 10^{6}$ tonnes of $\mathrm{CO}_{2}$ with an in situ density of $\sim 700 \mathrm{~kg} \mathrm{~m}^{-2}$ was injected at the base of the $200 \mathrm{~m}$ thick Utsira sand. Seismic images in 1999 and 2001 show a vertical column of gas with dimensions of roughly $1 \times 2 \mathrm{~km}$ in plan section. A small central gas-filled "chimney" appears to be filling sand lenses capped by minor shale units. The lateral capillary confinement is less effective than we envision for methane gas chimneys, but the gas density is much greater and the filling rate very different. Nevertheless the confinement to a gas column may be due to lateral capillary seals and thus may be a good analogue for the model we propose here for gas chimney development. (Zweigel et al., 2004; Arts et al., 2004; Chadwick et al., 2004). The impact of gas exsolution on oil production, another possible analogue for the lateral capillary seals in our model, has been discussed by Erendi and Cathles (2001).

The growing gas chimney propels water upward and away from the chimney. We envision that at this stage the gas saturates the pore space in the chimney and thus moves easily through it with little viscous resistance. Under this circumstance, the buoyancy of the chimney is sufficient to deform the sediments above the chimney and to produce a dome when its top is about half way to the seafloor. As soon as such pathways are competitive with simply moving water aside, water is expelled through any and all of the microfractures or other features that provide permeable pathways to the surface. If the rate of water expulsion is rapid enough to make the sediments quick, sediment grains can be lifted above the seafloor and carried off by ocean currents. Unit pockmarks form, increase in number, and merge into a fully grown pockmark that has the diameter of the chimney. To the sides of, or over a chimney that does not reach the surface, unit pockmarks may be preserved.

When the source gas is exhausted and the pressure at the seal again approaches hydrostatic, capillary forces will draw water into the strata above the pocket and the capillary seals at the top of the decompressed gas pocket will re-heal (Cathles, 2007). At this point all gas leakage from the gas pocket will cease, but it will take some time for the gas chimney to drain its gas and it will never drain completely. Some residual gas will remain in the chimney and thus the chimney will remain seismically visible. Zones adjacent to the chimney that have had some minor amounts of gas injected may appear acoustically turbid.

Gas-driven water expulsion can happen repeatedly, and the repeat time is that necessary for gas to accumulate sufficiently in the source pocket for the entry pressure of its top seal to again be exceeded. This filling time might be estimated using the methods of basin modeling. For example if the gas generation rate and catchment area for the pocked could be estimated, the time to fill to failure might be estimated. Subsequent pulses of gas will be expelled in the same location mainly because seal failure will occur at structural highs of the seal where the overpressure is greatest. Since these structures will not shift position, this venting will occur in the same location.

If gas generated in the subsurface cannot migrate into pockets (which can feed gas chimneys and form pockmarks), a buoyant gaswater-mud slurry will be produced that may feed mud diapirs and volcanoes. Whether gas release occurs by mud volcanoes or gas chimneys thus depends on whether subsurface gas can leave its source strata or not. Gas could accumulate in overpressured pockets and feed gas chimneys if their bounding seals rupture or fail by hydrofracture, but we do not discuss this situation in this paper.

\section{Quantitative model}

More can be learned if we quantify the conceptual model. Consider first the rate at which the gas chimney will rise toward the surface from a gas pocket trapped by a capillary seal which has failed. Since the viscosity of methane under shallow sub-seafloor conditions is $\sim 60$ times less than water (see Table 1 ), the main resistance to the upward migration of the gas chimney will be moving the overlying water aside so that gas (and the chimney) can move upward. Thus we assume that the gas pipe behaves like a piston moving vertically as a unit and is resisted by water being displaced radially from the top of the advancing piston as shown in Fig. 4. By mass balance, the flux of water from a hemisphere of the same radius as the chimney will be:

Table 1

Definition and selected values of parameters used in the calculations presented in this Appendix and paper.

\begin{tabular}{|c|c|c|c|}
\hline Parameters & Definition & Value & Reference \\
\hline$d[\mathrm{~m}]$ & Thickness of gas column beneath hydrate & & \\
\hline$d_{\mathrm{g}}[\mathrm{m}]$ & Diameter of sediment grain & & \\
\hline$f$ & $\begin{array}{l}\text { Factor spanning two types of chimney } \\
\text { pressure }\end{array}$ & $0-1$ & \\
\hline$\Phi$ & Sediment porosity & $55 \%$ & \\
\hline$g\left[\mathrm{~m} / \mathrm{s}^{2}\right]$ & Gravitational acceleration & 9.81 & \\
\hline$h[\mathrm{~m}]$ & Thickness of hydrate stability zone & & \\
\hline$h_{\mathrm{w}}[\mathrm{m}]$ & Height of water flow in fluid channel & & \\
\hline$h_{\mathrm{g}}[\mathrm{m}]$ & Height of gas flow in fluid channel & $=h-h_{\mathrm{w}}$ & \\
\hline$h_{\mathrm{wq}}[\mathrm{m}]$ & $\begin{array}{l}\text { Depth below seafloor where sediments } \\
\text { become quick }\end{array}$ & & \\
\hline$k_{0}\left[\mathrm{~m}^{2}\right]$ & Intrinsic permeability & & Appendix \\
\hline$k\left[\mathrm{~m}^{2}\right]$ & Permeability & & \\
\hline$k_{\mathrm{rW}}\left[\mathrm{m}^{2}\right]$ & Relative permeability of water & 1 & \\
\hline$k_{\mathrm{rg}}\left[\mathrm{m}^{2}\right]$ & Relative permeability of gas & 1 & \\
\hline$\mu_{\mathrm{w}}[\mathrm{Pa} \mathrm{s}]$ & Dynamic viscosity of water at $15^{\circ} \mathrm{C}$ & $\begin{array}{l}1.136 \mathrm{E} \\
-3\end{array}$ & $\begin{array}{l}\text { Lomax et al. } \\
(2001)\end{array}$ \\
\hline$\mu_{\mathrm{g}}[\mathrm{Pa} \mathrm{s}]$ & $\begin{array}{l}\text { Dynamic viscosity of gas at } 15^{\circ} \mathrm{C} \text {, } \\
267 \text { bars }\end{array}$ & $1.91 \mathrm{E}-5$ & $\begin{array}{l}\text { Earlougher } \\
\text { (1977) } \\
\text { Class et al. } \\
(2002)\end{array}$ \\
\hline$P_{\mathrm{c}}[\mathrm{Pa}]$ & Capillary pressure & & \\
\hline$\Delta P_{\mathrm{g}}[\mathrm{Pa}]$ & Pressure difference of gas flow & & \\
\hline$\Delta P_{\mathrm{w}}[\mathrm{Pa}]$ & Pressure difference of liquid flow & & \\
\hline$\Delta P[\mathrm{~Pa}]$ & Gas overpressure & & \\
\hline$r_{\mathrm{s}}[\mathrm{m}]$ & Effective radius of fine-grained layer & & \\
\hline$r_{1}[\mathrm{~m}]$ & Effective radius of coarse-grained layer & & \\
\hline$R[\mathrm{~m}]$ & Radius of gas chimney & $\sim 100 \mathrm{~m}$ & \\
\hline$\rho_{\mathrm{w}}\left[\mathrm{kg} / \mathrm{m}^{3}\right]$ & Water density & 1025 & \\
\hline$\rho_{\mathrm{g}}\left[\mathrm{kg} / \mathrm{m}^{3}\right]$ & Gas density at $15^{\circ} \mathrm{C} 267$ bars & 200 & $\begin{array}{l}\text { Behar et al. } \\
(1985)\end{array}$ \\
\hline$\rho_{\mathrm{s}}\left[\mathrm{kg} / \mathrm{m}^{3}\right]$ & Bulk density of sediment & 1800 & \\
\hline$S_{\mathrm{h}}$ & Hydrate saturation & & \\
\hline$t_{\text {chimney }}[\mathrm{s}]$ & Time for gas chimney to reach surface & & \\
\hline$\sigma\left[\mathrm{J} / \mathrm{m}^{2}\right]$ & Water-gas interfacial tension & 0.027 & $\begin{array}{l}\text { Vigil et al. } \\
\text { (1994) }\end{array}$ \\
\hline $\begin{array}{l}v_{\text {chimney }} \\
{\left[\mathrm{m} \mathrm{s}^{-1}\right]}\end{array}$ & Vertical velocity of a gas chimney & & \\
\hline$V[\mathrm{~m} / \mathrm{s}]$ & Volumetric fluid flux (Darcy velocity) & & \\
\hline
\end{tabular}




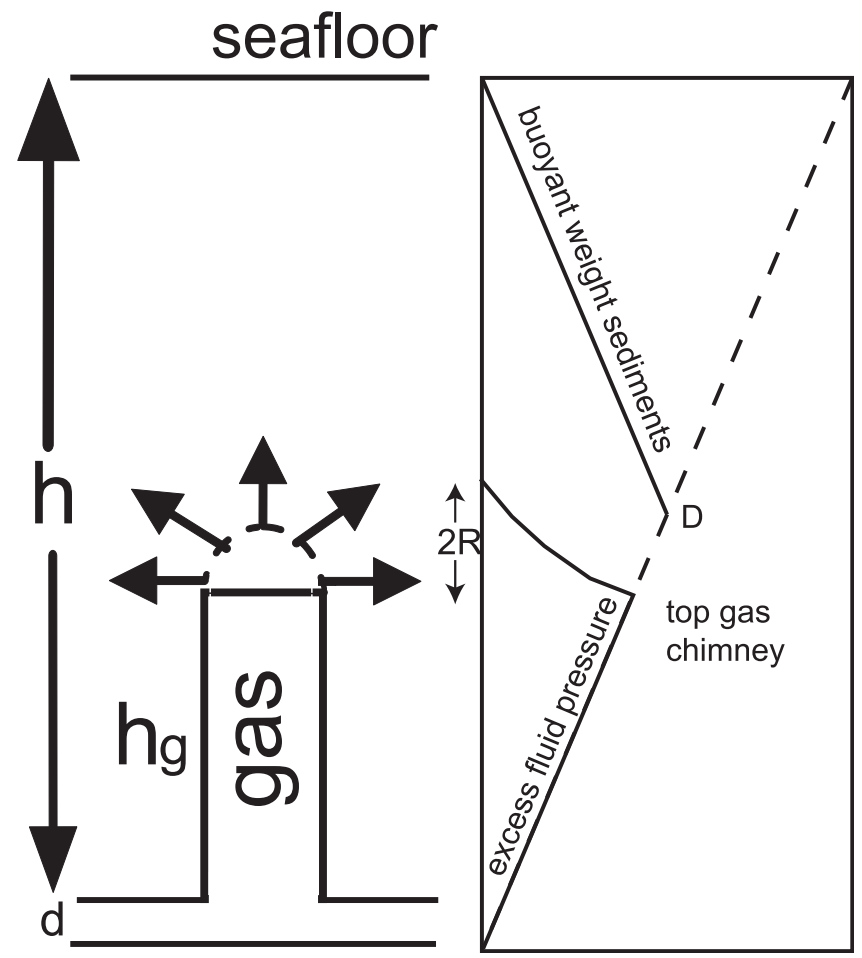

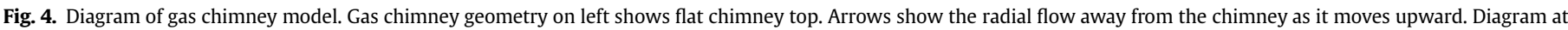

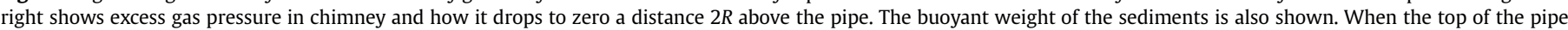

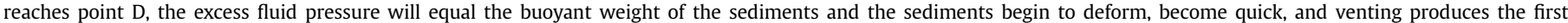
pockmarks as illustrated in Fig. 3.

$2 \pi R^{2} V=\phi \pi R^{2} v_{\text {chimney }}$

so

$V=\frac{\phi v_{\text {chimney }}}{2}$

where $R$ is the radius of the cylindrical gas chimney, $\phi$ is the porosity of the sediments, $v_{\text {chimney }}$ is the upward velocity of the chimney, and $V$ is the water flux on the hemispherical surface in $\mathrm{m}^{3}$ of water per $\mathrm{m}^{2}$ area per second. This flux is also known as the Darcy or superficial velocity of the water. All parameters are defined in Table 1 which also gives parameter values where appropriate.

Assuming that (1) the resistance to chimney migration displacing the water at its top (which is justified by the very low viscosity of gas compared to water in the situations considered here), and further that (2) the excess water pressure effectively drops to zero at a distance of $2 R$ (which is reasonable for the spherically radial flow), and (3) taking the driving pressure equal to a buoyant gas head of $d+h_{\mathrm{g}}$, the upward velocity of the chimney is:

$v_{\text {chimney }}=\frac{\partial h_{\mathrm{g}}}{\partial t}=\frac{2 k}{\phi \mu_{\mathrm{w}}} \frac{\left(\rho_{\mathrm{w}}-\rho_{\mathrm{g}}\right) g\left(d+h_{\mathrm{g}}\right)}{2 R}$.

Here $h_{\mathrm{g}}$ is the height of the gas chimney, $d$ the height of the gas leg under the seal at the time of failure (assumed to remain constant because sufficient lateral gas drains along the base of the seal to the leak point to make this so), and $\mu_{\mathrm{w}}$ is the viscosity of water.

Equation (1) can be integrated to determine the height of the gas chimney as a function of time:

$h_{\mathrm{g}}(t)=d\left(\mathrm{e}^{\frac{k\left(\rho_{\mathrm{w}}-\rho_{\mathrm{g}}\right) g t}{\phi \mu_{\mathrm{w}} R}}-1\right)$.
The time for the gas chimney to reach the surface is thus:

$t_{\text {chimney }}=\frac{\phi \mu_{\mathrm{w}} R}{k\left(\rho_{\mathrm{w}}-\rho_{\mathrm{g}}\right) g} \ln \left(\frac{h}{d}+1\right)$.

The rise time is very large if the gas leg at seal failure, $d$, is small because it takes a very long time for the chimney to get started without a significant initial pressure head.

The time required for a chimney to reach a fraction, $f$, of the way from the top of the gas pocket to the seafloor is given by (3) if $h$ is replaced by $f h$, and it can then be seen that the time to reach $f$ expressed as a fraction of the time to vent is:

$\frac{t}{t_{\text {chimney }}}=\frac{\ln (f h / d+1)}{\ln (h / d+1)}$.

Fig. 5 shows the time a gas chimney $200 \mathrm{~m}$ in diameter will take to reach the seafloor as a function of sediment permeability for various ratios of the depth to the gas pocket, $h$, to the length of the gas leg when the seal fails, $d$. Permeability is clearly the most important control on the time it will take a chimney to reach the seafloor after the seal on a gas pocket fails. Unless the near-surface sediments are extremely permeable, there will be a substantial time delay between episodes of seal failure, water and gas venting, and pockmark formation. The insert in Fig. 5, shows that the time a chimney with $h / d=7.3$ will take to reach half way to the seafloor is $73 \%$ of the time to reach the surface, and that the last $10 \%$ of the distance to the seafloor is traversed in $4 \%$ of the total time the pipe takes to reach the seafloor. The growth of the pipe accelerates as it approaches the seafloor because the gas buoyancy increases with the vertical extent of the chimney.

Now consider when pockmarks might form. They will form when the water flow above the chimney is rapid enough to make 


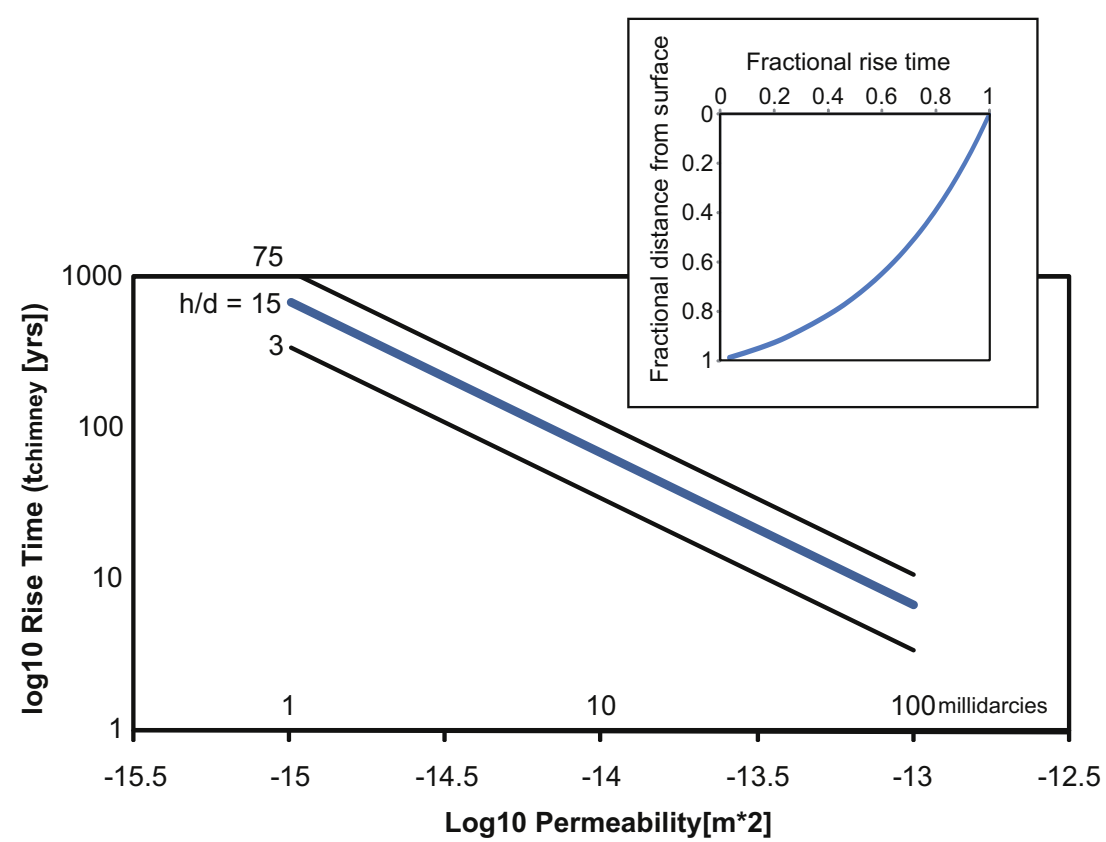

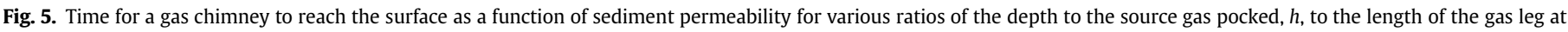

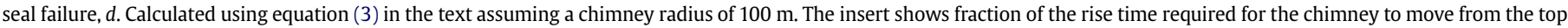
of the gas pocket to the surface.

the sediments quick. This will occur when the non-hydrostatic fluid pressure gradient equals to the buoyant lithostatic gradient and the effective stress goes to zero:

$V=\frac{k}{\mu_{\mathrm{w}}} \frac{\left(\rho_{\mathrm{w}}-\rho_{\mathrm{g}}\right) g\left(d+\left(h-h_{\mathrm{w}}\right)\right)}{h_{\mathrm{w}}}=\frac{k}{\mu_{\mathrm{w}}}\left(\rho_{\mathrm{s}}-\rho_{\mathrm{w}}\right) g$.

Rearranging we see that the water flow above the chimney could cause the sediments to become quick when the top of the chimney is at a depth $h_{\mathrm{wq}}$ :

$h_{\mathrm{w}}=h_{\mathrm{wq}}=(d+h) \frac{\left(\frac{\rho_{\mathrm{w}}-\rho_{\mathrm{g}}}{\rho_{\mathrm{s}}-\rho_{\mathrm{w}}}\right)}{1+\left(\frac{\rho_{\mathrm{w}}-\rho_{\mathrm{g}}}{\rho_{\mathrm{s}}-\rho_{\mathrm{w}}}\right)}=0.52(d+h)$.
To obtain the expression on the right we have substituted $\left(\left(\rho_{\mathrm{w}}-\rho_{\mathrm{g}}\right) /\left(\rho_{\mathrm{s}}-\rho_{\mathrm{w}}\right)\right)=1.06$, using the densities in Table 1.

Equation (5) shows that the sediments become quick when the gas chimney is about half way from the base of the gas pocket to the seafloor. This is also the point at which the buoyancy of the gas plume just equals the weight of the overlying sediments:

$\left(\rho_{\mathrm{w}}-\rho_{\mathrm{g}}\right) g\left(d+\left(h-h_{\mathrm{w}}\right)\right) d=\left(\rho_{\mathrm{s}}-\rho_{\mathrm{w}}\right) g h_{\mathrm{w}}$

Rearranging (6) also yields (5). The half-way point is labeled " $\mathrm{D}$ " in Fig. 4 . When the top of the chimney reaches this point the excess fluid pressure equals the buoyant weight of the overlying sediments and can deform and lift them. The reason for the half-way rule is

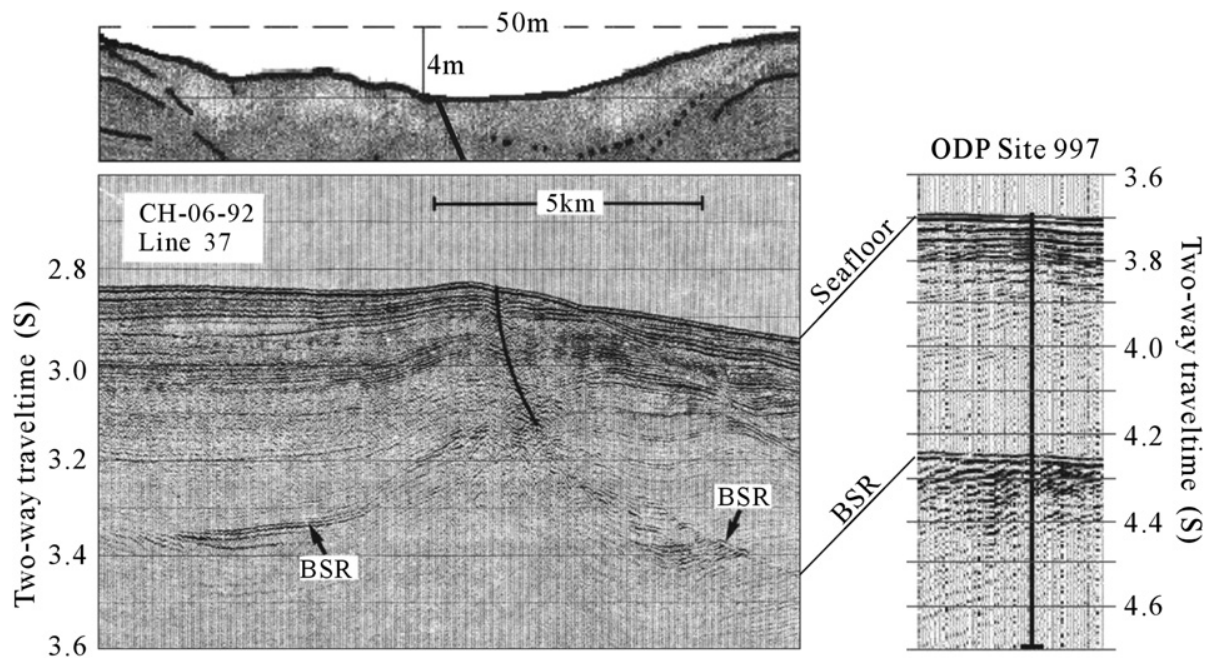

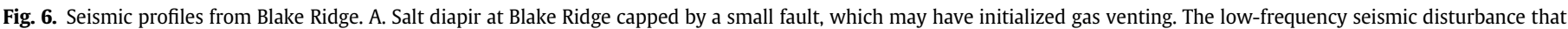

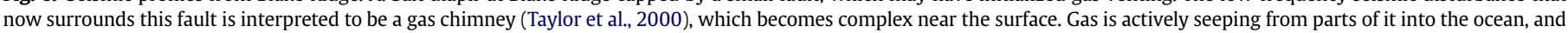

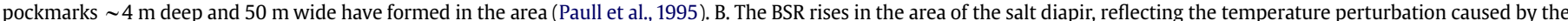

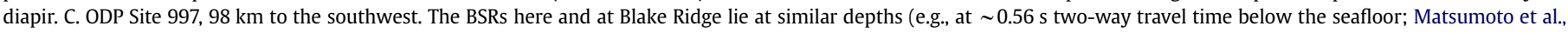
1996). 
that the positive buoyancy of the gas is almost exactly equal to the negative buoyancy of the sediments. Thus when the chimney extends half way to the surface, the buoyant pressure of the chimney gas equals the weight of the overlying sediments and can deform or even lift them. By the same token, this buoyant pressure could also drive water through the overlying sediments at just the rate that would levitate the sediment grains and cause them to become quick. Both phenomena depend only on buoyancy and are independent of permeability. Note we assume here that the shallow sediment density is constant, which is not necessarily the case.

We thus reach the somewhat surprising conclusion that a gas chimney can start to deform the sediments overlying it when its height equals half the depth of its base below the seafloor. The initial deformation is likely to utilize pre-existing weaknesses that become permeable flow pathways and produce a few pockmarks on the seafloor. As the gas plume continues to rise, the sediment deformation will become more severe, more pockmarks will form, the surface may dome more, and eventually a large pockmark over the gas chimney is likely to be produced. When the chimney reaches the surface, the gas will vent very rapidly (because its viscosity is 60 times less than water), and the gas pocket will drain. These last stages of pockmark formation will be dramatic. This is perhaps why Hovland and Judd (1988) and Judd and Hovland (2007) have suggested that pockmarks form catastrophically. Their last stages of formation will indeed tend to be catastrophic, but their early stages of formation will be barely perceptible. Surface deformation and the quickening of surface sediments that could disturb an offshore structure will happen toward the end of this phase. After pockmark formation and the final dramatic gas discharge has reduced the gas pressure in the source gas pocket, the capillary seals that trapped the gas may reheal by imbibing water. If gas again accumulates to a thickness $d$, the chimney formation and draining process can repeat itself in a very similar fashion as before. If, on the other hand, water is not imbibed to reform the seal, weak gas leakage may persist and this could prevent the gas accumulation at depth that could produce a second episode of pockmark formation. If the seal re-heals, post-pockmark gas venting will derive only from the gas chimney.

\section{Application to Blake Ridge}

At Blake Ridge off the Carolina coast pockmarks roughly $50 \mathrm{~m}$ diameter and $4 \mathrm{~m}$ deep form above gas plumes along a line of 20 salt diapirs (Paull et al., 1995). Fig. 6 shows a typical pockmark above the southernmost salt diapir. The bottom simulating reflector (BSR) is elevated near the salt dome because the thermally conductive salt has increased the geothermal gradient. Salt diapirism faulted the superjacent sediments, creating pathways for migration of water and gas to the seafloor at $2167 \mathrm{~m}$ water depth. Sonar surveys show generally low backscatter, but $\sim 50$ m diameter patches of much higher backscatter are associated with seafloor depressions up to $4 \mathrm{~m}$ depth. Gas-rich plumes that rise $320 \mathrm{~m}$ above the pockmarked seafloor can be seen in shipboard sonar. Gas venting through the pockmarks supports active chemosynthetic communities here, as elsewhere (Hovland, 2008).

A reasonable estimate for the gas column height at the time of seal failure at Blake Ridge is $\sim 30 \mathrm{~m}$. The seal in this case is the base of the hydrate stability zone (HSZ). Biogenic gas generated below the HSZ migrates upward and hydrate starts to crystallize and fills the sediment pores at this depth. The gas column that can be trapped below a hydrate seal depends on the amount of hydrate that has crystallized in the sediments at the base of the hydrate stability zone (HSZ). For Blake Ridge Liu and Flemings (2007) calculate that a gas column of $29 \mathrm{~m}$ could be trapped if $18 \%$ of the pores were filled with hydrate at the base of the HSZ (see Fig. 7).

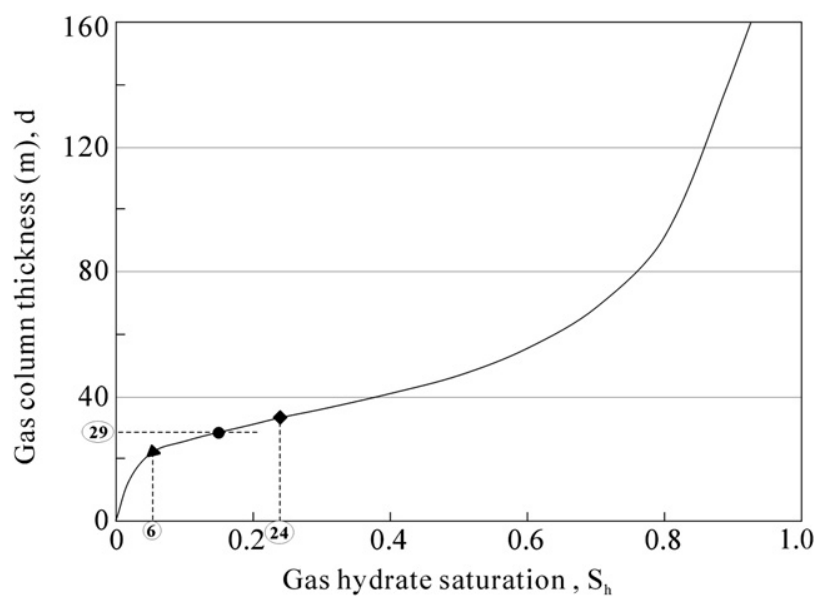

Fig. 7. Thickness of free gas column that will cause failure of a capillary seal produced by partial cementation of Blake Ridge sediment pores with hydrate calculated as in Appendix A. A hydrate saturation of $\sim 6 \%$ will trap a free gas interval of $20 \mathrm{~m}$. Hydrate saturation would need to be about $18 \%$ to trap a gas column with the thickness of $29 \mathrm{~m}$ gas predicted by Flemings et al. (2003). A gas $33 \mathrm{~m}$ column could be trapped by the $24 \%$ hydrate saturation measured by Su and Chen (2007) at the base of the HSZ at ODP site 997, about $100 \mathrm{~km}$ southwest of Blake Ridge.

At a BSR $98 \mathrm{~km}$ southwest of Blake Ridge that was penetrated by an ODP drill hole (see Fig. 6), Su and Chen (2007) determined that the gas saturation is $28 \%$ twenty-six meters below the thermodynamic base of the HSZ at 476 mbsf, and $0.2 \%$ seventy-four meters below this boundary. A gas fraction of $28 \%$ is somewhat higher than the $\sim 20 \%$ needed for gas mobility. A $0.2 \%$ gas saturation is well below this threshold. If the gas below the HSZ in this area has drained, and the $20 \%$ gas saturation boundary reflects the thickness of the gas-saturated layer that was present at Blake Ridge before the gas chimney formed, a gas leg thickness of $\sim 30 \mathrm{~m}$ at seal failure is indicated. The fraction of the pore space filled with hydrate at the base of the hydrate stability zone at Blake Ridge is 24\% (Su and Chen, 2007). From Fig. 7 it can be seen that this degree of hydrate fill will support a free gas column of $\sim 33 \mathrm{~m}$. This is similar to the $29 \mathrm{~m}$ gas column predicted by Flemings et al. (2003) for this site.

The gas plume initiated at the top of the salt dome. The temperature anomaly generated by the dome may be sufficient for the hydrate layer to arch over the dome. In any case, gas clearly is draining or has drained up the permeable sides of the dome to feed the gas chimney at its crest. Gas presumably collected at the top of the salt dome under a (hydrate or sediment) capillary seal until the entry pressure of the seal was exceeded and the chimney initiated. The depth of the gas pocket feeding the chimney is about half the $440 \mathrm{~m}$ to the surrounding BSR. A reasonable estimate for $h$ is $\sim 220 \mathrm{~m}$, and thus $h / d \sim 220 / 30=7.3$.

The permeability of the near-surface sediments at Blake Ridge is not known. It is difficult to measure the permeability of unconsolidated, $>60 \%$ porosity sediments near the seafloor. Nimblett and Ruppel (2003) estimate the permeability of the sediments in the HSZ at Blake Ridge assuming a sediment grain size of $1 \mu \mathrm{m}$ using the Kozeny Carmen equation (Appendix A), and also from fracture density using the methods of Snow (1968). By both methods they obtain a permeability of $\sim 10^{-13} \mathrm{~m}^{2}$. This permeability seems too high given that the sediments contain grains considerably finer than $1 \mu \mathrm{m}$. Shale/mud permeability depends strongly on porosity, and, for the $80 \%$ porosity that is common very near the seafloor, the permeability could be $\sim 10^{-15} \mathrm{~m}^{2}$ (=1 millidarcy; see Cathles and Adams, 2005, Fig. 17 and references therein). For these permeabilities, and $h / d \sim=7.3$, the gas plume at Blake Ridge would have taken a few years to a few hundred years or more (since shale 
compact rapidly with depth and thus have lower than $80 \%$ porosity) to reach the surface, and would have reached half way to the surface in about seven tenths of this time (Fig. 5 and equation (3)). But as discussed below sediment permeability may have increased greatly as they are deformed.

\section{Discussion}

Our analysis defines the factors and parameters that are important to pockmark formation by the venting of gas pockets. Most critical is that the capillary seal trapping the gas must fail, and not simply leak slowly. Seals can fail in primarily two ways: by injection of the trapped fluid or by hydrofracture. Quantitative discussion of these two possibilities is given in Revil and Cathles (2001). Here we have analyzed the case where the failure is by gas penetration. Failure by hydrofracture could result in similar gas chimney formation, but it is perhaps less likely that the venting of gas would be as complete. The analysis we make is valid given only that seal failure occurs and that the flow after failure is not significantly impeded by resistance in the invaded or ruptured seal. In this case the gas chimney can make sediments quick to a depth equal to about half that to the base of the gas pocket, and this will lead to a sequence of events remarkably similar to that inferred from seafloor observations articulated by Hovland and others. Pockmarks will be initially (at least) formed by venting of water that is propelled by gas. For a hazard prediction, gas venting is therefore unlikely to provide a useful warning. This appears to be supported by experiences reviewed above.

The unimportance of permeability as a parameter controlling pockmark formation is interesting. Permeability is, however, vital to the rate at which a gas chimney will rise. Very high sediment permeability is required for chimneys to reach the seafloor in less than a decade. If chimneys rise quickly, and if the upward movement of a gas chimney could be detected (by microseisms, streaming potential anomalies, or some other method), useful warning of a pockmark event might be possible. Concern should be high if there is any suggestion of a gas chimney under an area that extends half way to the surface. The vertical rate of growth of the chimney accelerates as it rises toward the seafloor even assuming the sediment permeability is vertically constant. Better constraining near-surface permeability of high porosity ocean sediment would allow better estimates of gas chimney rise rates. It should be kept in mind, however, that sediment deformation or dilation by the slightly overpressured waters may strongly affect sediment permeability. In this context, sediment permeability may be dynamically set and not be an extrinsic, measurable parameter.

Gas leg height at seal failure is the second most important factor determining the rise time of a gas chimney. Better documentation of the gas leg lengths required to initiate particular gas chimneys would improve estimates of chimney rise time.

It is unfortunate that the two parameters most critical to our analysis (gas leg height and permeability) are so poorly constrained. Constraints might be obtained from the rise time of gas chimneys if this were known accurately enough, but unfortunately it is not. One suspects chimneys must rise rapidly because gas chimneys penetrate very recently deposited strata. But the chimneys could have started to rise 1000 years ago. Geological constraints on the total time for chimney growth are not a tight enough to be useful.

As far as we know a capillary perspective on gas chimney width is new. In our analysis, which is also new, we ignore the capillary pressure drops where water and gas are mixed in a transition zone above the gas chimney. The capillary pressure barriers in this interval will have little impact provided they are cumulatively small compared to the excess pressure provided by the gas column. If they are not cumulatively comparatively small, the rise time of the chimney will be reduced, but there is so much uncertainty in our estimates of sediment permeability that this possibility is not significant at this stage.

A related issue involves the drainage of gas from the chimney after the gas pocket is decompressed sufficiently for the seal to reheal. Some drainage will occur as gas in the chimney decompresses. In addition, if the lateral capillary seals were weak, capillary forces could pull water into the chimney and cause further gas to drain upwards. In this context it would be very interesting to know the gas saturation in gas chimneys. A high gas chimney gas saturation would suggest the lateral seals are competent and perhaps good analogues to the capillary seals that bound accumulations of basincenter gas.

In its early stages, pore waters will utilize all permeable pathways and thus unit pockmark formation on minor fractures is expected as a precursor to more vigorous and ubiquitous flow as the gas chimney moves closer to the surface. Clustering and melding of unit pockmarks is also expected, and the observation that they meld to form a pockmark with the chimney diameter should be of no surprise. The depth of pockmark excavation will depend on the vigor and duration of water and gas outflow, and also on how effectively bottom currents can remove the quickened sediments. We do not consider these processes here.

The capillary model for the lateral confinement of gas chimneys may find some support from time-lapse seismic surveys at Sleipner that show how $\mathrm{CO}_{2}$ injection is filling a laterally confined gas column. Although the situations are very different in many regards, the analysis offered here may be of interest to issues of $\mathrm{CO}_{2}$ sequestration.

\section{Conclusions}

Pockmarks can form wherever fluid is expelled from the seafloor. We propose that a particularly common kind of pockmark, those associated with gas-rich sediments, forms as the result of the failure of a capillary seal that traps a subsurface gas pocket. When the seal fails, the gas pocket drains into a gas chimney which has a relatively flat top and cylindrical form because of minor capillary barriers in the transition zone from the gas chimney proper (with very low water saturation) to the fully water-saturated sediments surrounding it. Analytical expressions are developed to estimate the depth to which water propelled by the growing gas chimney can make sediments quick. This depth is shown to depend on the buoyancy of sediments and pore gas and not permeability. Since the buoyancies are about equal for gas and sediment, sediment deformation and pockmark formation above a gas chimney are expected to begin when the chimney reaches about half the distance from its source to the seafloor. The rate at which the gas chimney rises depends on sediment permeability and the ratio of the depth of the top of the source gas pocket to the thickness of the gas leg at the time of seal failure. Neither this ratio nor near-surface sediment permeability is well constrained, but for plausible estimates the rise of gas chimney may be years to centuries or more.

The analysis suggests that gas venting will not provide a useful warning of seafloor instabilities related to impending pockmark formation because in most cases gas will vent only after surface sediments have become quick. However, if the rise of the gas chimney could be detected, this could provide useful advance warning. Any areas underlain by a chimney that extends close to half way to the surface should be avoided. The gas saturation in a dormant chimney would be a valuable parameter to determine, because if the gas saturation were high, strong capillary seals bounding the chimney would be suggested. Better constraints on the gas leg at the time of seal rupture, and the permeability of 
marine sediments within a few hundred meters of the seafloor would narrow the range of model predictions. Pockmarks could potentially provide insights into capillary sealing and the conditions under which capillary seals leak or fail. Aspects of gas pipe formation and venting model may of interest to $\mathrm{CO}_{2}$ sequestration.

\section{Acknowledgements}

This study was supported by 973 Program (2009CB219508) and the National Science Foundation of China (Grant: 40725011 and U0733003). China Scholarship Council supports Zheng Su study in Cathles' Lab at Cornell University. We thank Fridtjof Riis for stimulating discussions and information, and Martin Hovland for references and reprints. The manuscript was substantially improved by the suggestions of two anonymous reviewers.

\section{Appendix A. Hydrate saturation and gas column height}

The porosity change due to hydrate formation is:

$\phi=\phi_{0}\left(1-S_{\mathrm{h}}\right)$

The porous medium is approximated as bundle of capillary tubes and hydrate forms in the center of each capillary, the change in intrinsic permeability is (Kleinberg et al., 2003)

$k=k_{0}\left[1-S_{\mathrm{h}}^{2}+\frac{2\left(1-S_{\mathrm{h}}\right)^{2}}{\log \left(S_{\mathrm{h}}\right)}\right]$

The grain diameter, $d_{\mathrm{g}}$, is suggested by the Carmen-Kozeny relationship (Bear, 1972):

$d_{\mathrm{g}}=\frac{1-\phi}{\phi} \sqrt{\frac{180 k}{\phi}}$

The effective pore radius, $r$, is 0.326di (Shosa \& Cathles, 2001). The capillary entry pressure of gas, $\Delta P_{c}$, from Laplace's law (Bear, 1972) is:

$\Delta P_{\mathrm{c}}=2 \sigma\left(\frac{1}{r_{\mathrm{s}}}-\frac{1}{r_{\mathrm{l}}}\right)$

Free gas is blocked in small pore space by capillary force. The maximum height of gas entrapped by the capillary barriers, $d$, can be calculated by the relation:

$\Delta P_{\mathrm{c}}=\left(\rho_{\mathrm{w}}-\rho_{\mathrm{g}}\right) g d=\Delta P$

\section{References}

Arts, R., Eiken, O., Chadwick, A., Zweigel, P., Van der Meer, B., Kirby, J., 2004. Seismic monitoring at the Sleipner underground $\mathrm{CO}_{2}$ storage site (North Sea). In: Baines, S.J., Worden, R.H. (Eds.), Geological Storage of Carbon Dioxide. Geological Society, London, Special Publications, vol. 233, pp. 181-191.

Bear, J., 1972. Dynamics of Fluids in Porous Media. Dover Publications Inc., New York. 764pp.

Behar, E., Simonet, R., Rauzy, E., 1985. A new cubic equation of state. Fluid Phase Equilibria 21, 237-255.

Cathles, L.M., 2001. Capillary seals as a cause of pressure compartmentation in sedimentary basins. In: Petroleum Systems of Deep-Water Basins: Global and Gulf of Mexico Experience: Proceedings of the Gulf Coast Section Society of Economic Paleontologists and Mineralogists Foundation, 21st Annual Bob F. Perkins Research Conference, pp. 561-572.

Cathles, L.M., 2003. Gas: a messenger from subsurface resources. GasTIPS 9 (2), 25-27.

Cathles, L.M., 2007. Changes in sub-water table fluid flow at the end of the Proterozoic and its implications for gas pulsars and MVT lead-zinc deposits. Geofluids 7 (2), 209-226.

Cathles, L.M., Adams, J.J., 2005. Fluid flow and petroleum and mineral resources in the upper $(<20 \mathrm{~km})$ continental crust. Economic Geology 100th Anniversary Volume, 77-110.
Chadwick, R.A., Holloway, S., Brook, M.S., Kirby, G.A., 2004. The case for underground $\mathrm{CO}_{2}$ sequestration in northern Europe. In: Baines, S.J., Worden, R.H. (Eds.), Geological Storage of Carbon Dioxide. Geological Society, London, Special Publications, vol. 233, pp. 17-28.

Class, H., Helmig, R., Bastian, P., 2002. Numerical simulation of non-isothermal multiphase multicomponent processes in porous media. 1. An efficient solution technique. Advances in Water Resources 25, 533-550.

Dimitrov, L., Woodside, J., 2003. Deep sea pockmarks environments in the eastern Mediterranean. Marine Geology 195, 263-276.

Earlougher, R.C., 1977. Advances in Well Test Analysis. Monograph 5. Society of Petroleum Engineers, New York. 264pp.

Eichhubl, P., Greene, H.G., Naehr, T., Maher, N., 2000. Structural control of fluid flow: offshore fluid seepage in the Santa Barbara Basin, California. Journal of Geochemical Exploration 69/70, 545-549.

Erendi, A., Cathles, L.M., 2001. Gas capillary inhibition to oil production. In: Petroleum Systems of Deep-Water Basins: Global and Gulf of Mexico Experience: Proceedings of the Gulf Coast Section Society of Economic Paleontologists and Mineralogists Foundation, 21st Annual Bob F. Perkins Research Conference, p. Petroleum Systems of Deep-Water Basins: Global and Gulf of Mexico Experience, Houston, Texas, pp. 607-618.

Flemings, P.B., Liu, X., Winters, W.J., 2003. Critical pressure and multiphase flow in Blake Ridge gas hydrates. Geology 31, 1057-1060.

Gay, A., Lopez, M., Berndt, C., Seranne, M., 2007. Geological controls on focused fluid flow associated with seafloor seeps in the Lower Congo Basin. Marine Geology 244 (1-4), 68-92.

Gay, A., Lopez, M., Cochonat, P., Seranne, M., Levache, D., Sermondadaz, G., 2006a. Isolated seafloor pockmarks linked to BSRs, fluid chimneys, polygonal faults and stacked Oligocene-Miocene turbiditic palaeochannels in the Lower Congo Basin. Marine Geology 226 (1-2), 25-40.

Gay, A., Lopez, M., Ondreas, H., Charlou, J--L., Sermondadaz, G., Cochonat, P., 2006b. Seafloor facies related to upward methane flux within a giant pockmark of the Lower Congo Basin. Marine Geology 226 (1-2), 81-95.

Hovland, M., 1989. Modern analogues to middle Ordovician sedimentary mounds and washout depressions. Journal of Sedimentary Petrology 59, 585-589.

Hovland, M., 2005. Pockmark-associated coral reefs at the Kristin field off MidNorway. In: Freiwald, A., Roberts, J.M. (Eds.), Cold-water Corals and Ecosystems. Springer-Verlag, Berlin, pp. 623-632.

Hovland, M., 2008. Deep-water Coral Reefs, Unique Biodiversity Hotspots. Springer, Chichester. 278pp.

Hovland, M., Judd, A.G., 1988. Seabed Pockmarks and Seepages. Impact on Geology, Biology and the Marine Environment. Graham \& Trotman Ltd. London, $293 \mathrm{pp}$.

Hovland, M., Gardner, J.V., Judd, A.G., 2002. The significance of pockmarks to understanding fluid flow processes and geohazards. Geofluids 2, 127-136.

Hovland, M., Svensen, H., Forsberg, C.F., Johansen, H., Fichler, C., Fossa, J.H. Jonsson, R., Rueslatten, H., 2005. Complex pockmarks with carbonate-ridges off mid-Norway: products of sediment degassing. Marine Geology 218, 191-206.

Hovland, M., Svensen, H., 2006. Submarine pingoes: indicators of shallow gas hydrates in a pockmark at Nyegga, Norwegian Sea. Marine Geology 228, 15-23.

Judd, A., Hovland, M., 2007. Seabed Fluid Flow. Cambridge University Press, Cambridge. 475pp.

King, L.H., MacLean, B., 1970. Pockmarks on the Scotian shelf. Geological Society of America Bulletin 81, 3141-3148.

Kleinberg, R.L., Flaum, C., Griffin, D.D., et al., 2003. Deep sea NMR; methane hydrate growth habit in porous media and its relationship to hydraulic permeability deposit accumulation, and submarine slope stability. Journal of Geophysical Research 108 (B10)

Liu, X., Flemings, P.B., 2007. Dynamic multiphase flow model of hydrate formation in marine sediments. Journal of Geophysical Research 112, B03101. 10.1029/ 2005JB004227.

Lomax, H., Pulliam, T.H., Zingg, D.W., 2001. Fundamentals of Computational Fluid Dynamics. Springer-Verlag, New York.

Matsumoto, R., Paull, C., Wallace, P., and the Leg 164 Scientific party, 1996. Gas hydrate sampling on the Blake Ridge and Carolina Rise: ODP. Leg 164 Preliminary Report.

Nimblett, J., Ruppel, C., 2003. Permeability evolution during the formation of gas hydrates in marine sediments. Journal of Geophysical Research 108 (B9), 1-17. doi:10.1029/2001JB001650.

Paull, C.K., Spiess, F.N., Ussler III, W., Borowski, W.A., 1995. Methane-rich plumes on the Carolina continental rise: associations with gas hydrates. Geology 23, 89-92.

Paull, C.K. Ussler III, W., Holbrook, W.S, et al, 2008, Origin of pockmarks and chimney structures on the flanks of the Storegga Slide, offshore Norway. GeoMarine Letters 28 (1), 43-51.

Revil, A., Cathles, L.M., 2001. The porosity-depth pattern defined by 40 wells in Eugene Island South Addition, Block 330 Area, and its relation to pore pressure, fluid leakage, and seal migration. In: Petroleum Systems of Deep-Water Basins: Global and Gulf of Mexico Experience: Proceedings of the Gulf Coast Section Society of Economic Paleontologists and Mineralogists Foundation, 21st Annual Bob F. Perkins Research Conference, pp. 687-712.

Schmuck, E.A., Paull, C.K., 1993. Evidence for gas accumulation associated with diapirism and gas hydrates at the head of the Cape Fear Slide. Geo-Marine Letters 13, 145-152.

Shaw, J., Courtney, R.C., Currie, J.R., 1997. Marine geology of St. George’s Bay, Newfoundland, as interpreted from multibeam bathymetry and back-scatte data. Geo-Marine Letters 17, 188-194.

Shosa, J.D., Cathles, L.M., 2001. Experimental investigation of capillary blockage of two-phase flow in layered porous media. In: Petroleum Systems of Deep-Wate 
Basins: Global and Gulf of Mexico Experience: Proceedings of the Gulf Coast Section Society of Economic Paleontologists and Mineralogists Foundation, 21st Annual Bob F. Perkins Research Conference, pp. 725-739.

Snow, D.T., 1968. Rock fracture spacings, openings, and porosities. Journal of the Soil Mechanics and Foundations Division, American Society of Civil Engineers 94 (SM1), 73-91.

Su, Z., Chen, D., 2007. Calculation of methane hydrate solubility in marine environment and its constraints on gas hydrate occurrence. Chinese Journal of Geophysics 50 (5), 1518-1526.
Taylor, M.H., Dillon, W.P., Pecher, I.A., 2000. Trapping and migration of methane associated with the gas hydrate stability zone at the Blake Ridge Diapir: new insights from seismic data. Marine Geology 164, 79-89.

Vigil, G., Xu, Z., Steinberg, S., Israelachvili, J., 1994. Interactions of silica surfaces. Journal of Colloid and Interface Science 165, 367.

Zweigel, P., Arts, R., Lothe, A.E., Linderberg, E.B.G., 2004. Reservoir geology of the Utsira Formation at the first industrial-scale underground $\mathrm{CO}_{2}$ storage site (Sleipner area, North Sea). In: Baines, S.J., Worden, R.H. (Eds.), Geological Storage of Carbon Dioxide. Geological Society, London, Special Publications, vol. 233, pp. 165-180. 